\title{
Viability of a random pattern dorsal skin flap, in diabetic rats ${ }^{1}$
}

\author{
Viabilidade do retalho cutâneo randômico dorsal em ratos diabéticos
}

\author{
Eliziane Nitz de Carvalho², Lydia Masako Ferreira ${ }^{3}$, Nestor Antônio Schmidt de Carvalho ${ }^{4}$, Luiz Eduardo Felipe Abla ${ }^{5}$, \\ Richard Eloin Liebano ${ }^{6}$
}

1. Plastic Surgery Laboratory of Plastic Division of Federal University of São Paulo- UNIFESP.

2. Master in Basic Sciences in Plastic Surgery Division of Federal University of São Paulo - UNIFESP.

3. Head of Plastic Surgery Division of Surgery Department and Coordenador of Post-graduation Program in Reconstructive Plastic Surgery - UNIFESP.

4. Master in Neurophysiology, teacher of Physiology in courses at UNIVALI.

5. Teacher of Post-graduation Program in Reconstructive Plastic Surgery of UNIFESP.

6. Doctor in Basic Sciences in Plastic Surgery of Federal University of São Paulo - UNIFESP.

\begin{abstract}
Purpose: Evaluation of the viability of a random pattern dorsal skin flap, in rats with experimentally induced diabetes mellitus. Methods: Thirty adult, male, Wistar EPM rats were distributed, at random, in two groups: I - Control (flap elevation) and II - Experimental (flap elevation ten days after alloxan induced diabetes ). Results: The mean areas of necrosis in the different groups were 36.4\% (Control) and 52.1\% (Experimental). Conclusion: The random pattern dorsal skin flap was less viable in the diabetic rats.
\end{abstract}

Key words: Diabetes mellitus. Cutaneous flap. Aloxane. Rats.

\section{RESUMO}

Objetivo: Avaliar a viabilidade do retalho cutâneo randômico dorsal em ratos experimentalmente induzidos ao diabetes mellitus. Métodos: Foram utilizados 30 ratos Wistar, adultos, machos, distribuídos em 2 grupos: I - controle - submetidos somente ao retalho cutâneo e II - experimental - submetidos ao retalho cutâneo após 10 dias da indução do diabetes mellitus com aloxano. Resultados: O grupo controle teve 36,39\% e o grupo experimental 52,06\% de média de área de necrose. Conclusão: A viabilidade do retalho cutâneo randômico dorsal foi menor no rato diabético do que no rato normal. Descritores: Diabetes mellitus. Retalho cutâneo. Aloxano. Ratos.

\section{Introduction}

Due to its high prevalence and potential deleterious effects on a patient's physical and psychological state, diabetes mellitus, which can result in a morbid condition, is a major medical concern ${ }^{1,2}$. According to the World Health Organization (WHO) the number of diabetics has doubled in the past few years and is expected to double once again by the year 2025. Today, there are 160,000 diabetics worldwide, 10,000 only in Brazil, which makes the country the sixth in the world rank ${ }^{3}$. In humans, diabetes mellitus is one of the most prevalent conditions with spontaneous manifestation. In animals, it can be induced by partial pancreatectomy or by the administration of diabetogenic drugs such as alloxan ${ }^{4}$.

These agents selectively destroy the Langerhans islet â-cell. The best known drug-induced diabetes model is the alloxan diabetes. Alloxan, a derivative of uric acid, as well as of other substance of different chemical groups, cases âcells to degranulate and consequently degenerate $e^{1,5,6,7,8,9,10}$. Skin flaps are largely used in all fields of plastic surgery, especially in reconstructives ${ }^{11}$. They have been utilized for centuries and, during this time, one concerning has been to develop techniques to provide more assurance in skin flap realization. The research of skin flaps survival mechanisms and your possible curate factors have been issue for publications ${ }^{12,13,14}$.

The purpose of this experimental study was to evaluate the viability of a random pattern dorsal skin flap, in rats with alloxan induced diabetes.

\section{Methods}

This study was approved by Commission of ethics in Research of Federal University of Sao Paulo. All the procedures followed, rigorously, the existent regulations about animal experimentation. Thirty adult, male, Wistar EPM rats, weighting around $300 \mathrm{~g}$, were distributed, at random, in two groups of 15 animals: I - Control, exposed to elevation of a skin flap; II - Experimental, exposed to flap elevation ten days after alloxan induced diabetes. The animals were individually allocated in cages, receiving standard food and water ad libitum. Rats in Group II were kept in 48 hours fast before diabetes induction. They were weighted and anesthetized by her inhalation in glass dome. A solution of alloxan at $2 \%$ diluted in saline at 0,9\% was administered to the animals in a single dose corresponding to $40 \mathrm{mg}$ of 
alloxan per $\mathrm{Kg}$ of animal weight injected into their penial vein ${ }^{15}$ (Figure 1).

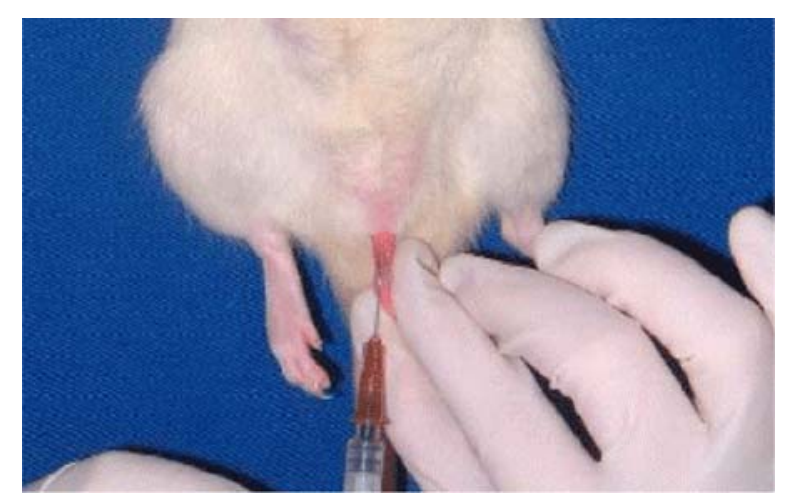

FIGURE 1 - Administration of a lloxan in the animal's penial vein.

In order to assess the effect of alloxan and to chemically establish the diabetic condition, an incision was done in any of the four veins in the tail of the rat using a 15 scalpel blade 10 days after the diabetes induction. A sample of the rat's venous blood was collected on a reagent strip 10 days after the diabetes induction procedure for blood glucose level determination using a portable glucose analyzer ${ }^{15}$ (Figure 2).

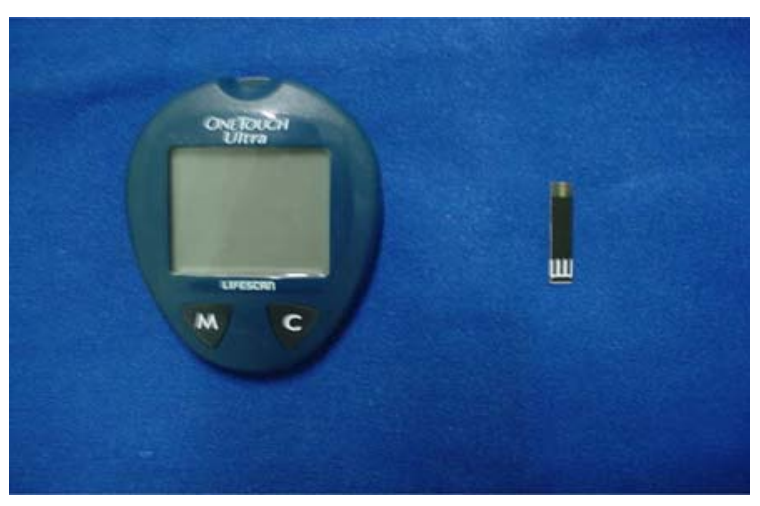

FIGURE 2 - Portable blood glucose test device.

The level of serum glucose considered to be normal in rattus novergicus ranges from 50 to $135 \mathrm{mg} / 100 \mathrm{ml}^{15}$. In this study, rats with glucose levels above $200 \mathrm{mg} / \mathrm{dl}$ were considered as having severe diabetes. After determination of the glicemic state, the rats were weighted again and after 24 hours, anesthetized with Tiletamin Chloridrate $(25 \mathrm{mg} / \mathrm{kg})$ and Zolazepam Chloridrate (25 mg/kg), intraperitoneally. Then, the animals were positioned over a flat surface, with extended limbs, their backs were shaved and a random pattern, cranially based dorsal skin flap was elevated. Delineation of the flap was done in the dorsum of the rats by means of a transparent plastic pattern, cut in the standard dimensions (4 x $10 \mathrm{~cm}$ ). The flap was then incised with scalpel, being elevated in a plane superficial to the deep muscular fascia, including the superficial fascia, paniculum carnosum, subcutaneous tissue and skin ${ }^{16}$. After flap elevation, an impermeable plastic barrier, cut in the same dimensions, was placed between the flap and its donor bed $^{17,18}$ (Figures3,4). After that, the rats were placed in individual cages, receiving food and water ad libitum. The percentage of skin flap necrosis area was calculated on the seventh postoperative day via the paper template method.

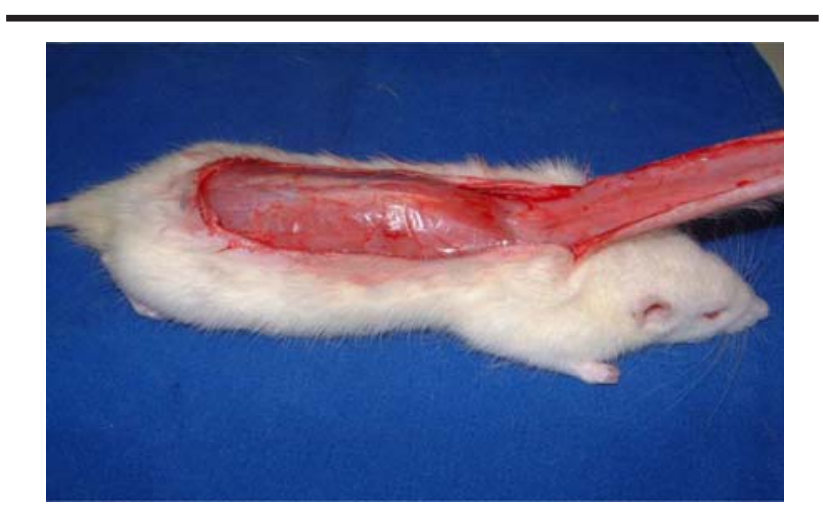

FIGURE 3 - Random skin flap raised.

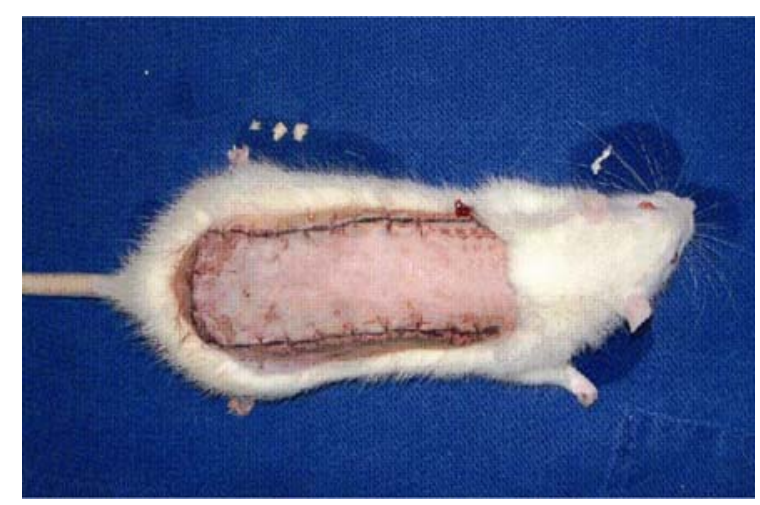

FIGURE 4 - Suture with 4-0 nylon stitches after the flap was raised and a plastic barrier was interpositioned.

The limit between viable tissue characterized by soft skin, rosy, warm and with hair and necrotic tissue by stiff skin, dark, cool and without hair was demarcated in the animals ${ }^{16}$ (Figures 5,6). A mould of entire flap was drawn and cut in transparent paper, being checked in a precision balance $(+/$ - $0,001 \mathrm{~g}$ error). It was cut from this fragment just the correspondent area to flap necrosis that was also checked.

After that, it was used the following formula:

$$
\begin{aligned}
& \text { weight of paper template } \\
& \begin{array}{l}
\text { Percentage of necrosis } \\
\text { area of the flap }
\end{array}=\frac{\text { of flap necrosis }}{\text { weight of paper template }} \times 100 \\
& \text { of total area of flap }
\end{aligned}
$$

Considering the nature of the data involved in this study, like percentage of necrosis, non parametric tests were used in the statistical analysis. The Mann-Whitney test (non parametric, independent groups) was used to compare groups 1 and 2 as regards the percentages of necrosis in the flaps. The significance level was fixed in 0.05 or $5 \%(<0.05)$. Significant values were marked (*); non significant values were identified as N.S.. The weights of the animals in the immediate preoperative period were compared using the " $\mathrm{t}$ " Student's test for independent groups (parametric, non paired). 


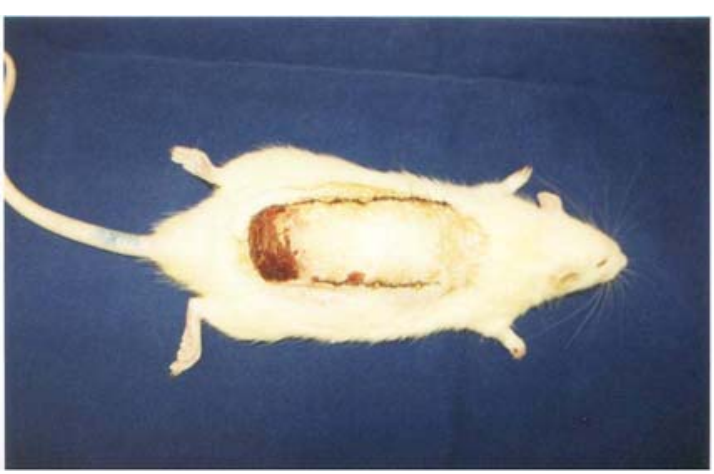

FIGURE 5 - Necrotic tissue (control animal).



FIGURE 6 - Necrotic tissue (experimental animal).

\section{Results}

All the alterations caracteristic of a diabetic rat were observed, like polydipsia, polyuria, weight loss, asthenia, dehydration and weight loss. Alongside with all these signs, the percentages of necrosis in the control animals varied from 24.2 to $46.9 \%$ (mean $36.4 \%$ ) and in the diabetic animals ranged between 35.5 and 54.9\% (mean 52.1\%) (Table 1, Figure 7).

TABLE 1 - Percentages of necrosis in the seventh postoperative day (\%).

\begin{tabular}{lcc}
\hline & Control Group & Experimental Group \\
\hline & 48,43 & 58,42 \\
& 34,71 & 66,95 \\
& 48,79 & 61,24 \\
& 20,80 & 53,32 \\
& 48,15 & 51,85 \\
& 31,06 & 39,72 \\
& 33,14 & 35,50 \\
& 46,82 & 54,00 \\
& 43,10 & 48,87 \\
& 24,25 & 60,69 \\
& 25,52 & 54,90 \\
& 40,42 & 48,31 \\
& 30,15 & 65,21 \\
\hline Mean & 37,78 & 40,17 \\
SD & 32,85 & 41,80 \\
\hline
\end{tabular}

“ $\mathrm{t}$ ” Test for independent groups / $\mathrm{t}$ calculated +4.53 $(\mathrm{p}<0.001)^{*} / \mathrm{G} 1<\mathrm{G} 2 *$

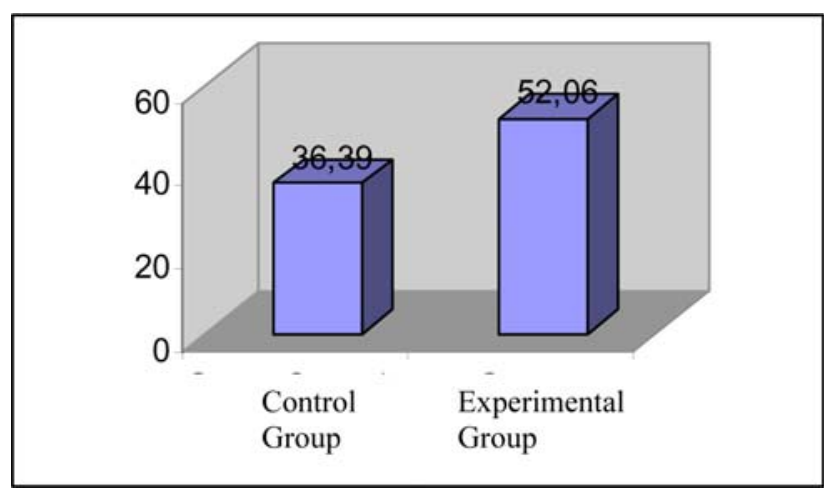

FIGURE 7 - Mean percentages of necrosis in the seventh postoperative day (\%).

\section{Discussion}

Experimental diabetes induced by chemical agents, such as alloxan, causes kidney lesions that are similar to human diabetic nephropathy. It is a derivative of uric acid, able to induce permanent diabetes in animals after 24 hours, due to its selective toxic effect on beta pancreatic cells, leading to a primary insulin insufficiency of the pancreas ${ }^{21,}$ 22. Alloxan may be administered intravenously, intraperitoneally or subcutaneously, but in the present study the intravenous route was chosen, based on the rapidity of the effect and the possibility of using a lower dose of this toxic substance. Alloxan, once administered intravenously, leads to diabetes by means of destruction of the pancreatic insular tissue, including the beta cells that produce insulin, which suffer degenerative alterations and necrosis. The result is a diabetic animal, an excellent experimental model to study organic alterations developed by insulin deficiency ${ }^{19}$.

Among the complications related to diabetes is tissular healing impairment. In diabetic patients, protein synthesis is reduced while catabolism is increased, with changes in the tissues' growing process, regeneration and reparation. Healing is altered due to problems in the proteic metabolism and fibroblasts depression. Skin flaps represent, often, the only adequate option for surgical repair after removal of skin lesions and tumors, specially when larger reconstructions are necessary, demanding adequate functional and aesthetic results.

The most common complication after reconstructions with flaps is partial necrosis ${ }^{3,4}$. This undesirable event demands more operative procedures, increasing hospitalization period and delaying the patients return to normal activities. Failure in the operation may make new reparation very difficult and mine the surgeon-patient relationship ${ }^{17}$. The most important aspect that rules the viability of a skin flap is adequate nutritive blood flow in the microcirculation.

In the present study, Control animals (Group I) had blood glucose levels between 60 and $94 \mathrm{mg} / \mathrm{ml}$, what according to the literature indicate normal rats, while Experimental animals (Group II) had glucose levels between 212 and $418 \mathrm{mg} / \mathrm{ml}$, evidencing an uncontrolled diabetic state. Besides hyperglycemia, it was observed that rats that received alloxan presented clinic signs of the disease, similar 
to those described for humans, polydipsia (abnormal thirst), polyuria (increased urine volume), weight loss (due to lean mass loss), asthenia (weakness due to the inability to use glucose as a source of energy), dehydration (due to the animal body's attempt to get rid of the excess blood glucose as the normal process of storing glucose in the body cells is impaired) and weight loss ${ }^{1}$.

The dorsal random pattern skin flap, cranially based, in the rat, used in the present work, was described by McFarlane et al. ${ }^{16}$, as an experimental flap model to study skin necrosis and its prevention. Dimensions are $10 \times 4 \mathrm{~cm}$. Usually, it is associated with a distal necrosis rate between 25 and $50 \%$, but in $5.7 \%$ of the animals there is no significant necrosis. In the herein presented study, percentages of necrosis in control animals (Group I) ranged between 20.8 and $48.4 \%$ (mean 36.4\%). In the experimental rats (Group II), the values ranged between 35.5 and 65.2\% (mean 52.1\%). Statistical analysis showed a significant difference between these groups. Uncontrolled diabetes increased the percentage of distal necrosis in this flap in relation to normal rats. Future perspectives involve the use of drugs able to reduce distal necrosis in this random skin flap in uncontrolled diabetic rats.

\section{Conclusion}

Uncontrolled diabetes reduced the viability of this random pattern skin flap in the rat.

\section{References}

1. Macedo CS, Capelletti SM, Mercadante MCS, Padovani CR, Spadella CT. Role of metabolic control in diabetic nephorathy. Acta Cir Bras. 2002; 17 (6): 370-5.

2. Halpen A, Mancini MC, Mancini MMAM. Diabetes mellitus. Rev Bras Med. 2000:57.

3. Costa M, Forti A. Diagnóstico e classificação do Diabetes mellitus e tratamento do Diabetes mellitus do tipo 2: recomendações da Sociedade Brasileira de Diabetes. Disponível em: http://www.diabetes.org.br/Diabetes/ consenso/consl.html. Acesso em 01 março 2003.

4. Cisternas JR. Fisiologia das ilhotas de Langerhans. In: Douglas CR. Tratado de fisiologia aplicada a ciências da saúde. 4 ed. São Paulo: Robe; 2000. p. 1073-86.

5. Ahrén R, Sundkvist G. Long term effects of alloxan in mice. Int J Pancreatol. 1995; 2: 197-201.
6. Calza KC, Marqueti RC, Silveira MPM. Efeito cicatrizante do laser HeNe atuando na cicatrização de tecidos cutâneos em ratos (aloxânicos) diabéticos e normais. Rev Bras Fisioter, 2001, supl 28.

7. Covington DS, Xue H, Pizzini R, Lally K, Andrassy RJ. Streptozotocin and aloxan are comparable agents in the diabetic model of impaired wound healing. Diabetic Rev. 1993; 23: 47-53.

8. Dunn Js, Mcletchie NGB. Experimental alloxan diabetes in the rat. Lancet. 1943; 245: 484-7.

9. Godoy P, Barreto Neto M. Pâncreas endócrino. In: Bogliolo L. Patologia $3^{\circ}$ ed. Rio de Jasneiro: Guanabara Koogan; 1981.p. 1056-60.

10. Machado JLM, Macedo AR, Silva MD, Spadella CT, Montenegro MRG. Caracterização de um modelo experimental de neuropatia em ratos diabéticos induzidos pela aloxana. Acta Cir Bras. 2000; 15 (2): 86-93.

11. Ferreira LM. Retalhos cutâneos. In: Ferreira LM. Manual de Cirurgia Plástica. São Paulo: Atheneu; 1995. p. 45-62.

12. Kerrigan CL. Skin flap failure: pathophysiology. Plast Reconstr Surg. 1983; 72: 766-77.

13. Gherardini G, Lundeberg T, Cui J, Erksson SV, Trubek S, Linderoth B. Spinal cord stimulation improves survival in ischemic skin flaps: an experimental study of the possible mediation by calcitonin gene-related peptide. Plast Reconstr Surg. 1999; 103:1221-8.

14. Salmi AM, Hong C, Futrell JW. Preoperative coolings and warming of the donor site increase survival of skin flaps by the mechanism of ischaemic preconditioning: an experimental study in rats. Scand J Plast Reconstr Hand Surg. 1999; 33: 163-7.

15. Carvalho EN, Carvalho NAS, Ferreira LM. Experimental model of induction of diabetes mellitus in rats. Acta Cir Bras [serial online] 2003 vol 18 Special Edition.

16. McFarlame RM, DeYoung G, Henry RA. The design of a pedicle flap in the rat to study necrosis and its prevention. Plast Reconstr Surg. 1965, 35: 177-82.

17. Duarte SI, Gomes HFC, Ferreira LM. Effect of dimethyl sulphoxide on necrosis of skin flaps in rats. Canadian J Plast Surg. 1998; 6 (2): 93-7.

18. Liebano RE, Ferreira LM, Neto MS. The effect of transcutaneos eletrical nerve stimulation on the viability of random skin flaps in rats. Can J Plast Surg. 2002; 10 (4): 151-4.

19. Pearl SH, Kanat IO. Diabetes and healing: a review of literature. J Foot Surg. 1988; 27 (3): 268-70.

\section{Correspondence:}

Eliziane Nitz de Carvalho

UNIFESP - EPM, Plastic Surgery Division

Rua Napoleão de Barros, 715/4 andar

04024-900 São Paulo-SP Brazil

fisioeliziane@yahoo.com.br
Conflict of interest: none Financial source: CAPES

Received: January 15, 2005

Review: February 22, 2005

Accepted: March 12, 2005

\section{How to cite this article:}

Carvalho EN, Ferreira LM, Carvalho NAS, Abla LEF, Liebano RE. Viability of a random pattern dorsal skin flap, in diabetic rats. Acta Cir Bras. [serial online] 2005 May-June;20(3). Available from URL: http://www.scielo.br/acb. 